\title{
Communications
}

\section{Épidémiologie des principaux virus à tropisme respiratoire chez les petits ruminants au Mali}

\author{
S. Maiga ${ }^{1}$
}

J. Sarr ${ }^{2}$

MAIGA (S.), SARR (J.). Épidémiologie des principaux virus à tropisme respiratoire chez les petits ruminants au Mali. Revue Élev. Méd. vét. Pays trop., 1992, 45 (1): 15-17

De 1986 à 1988, une enquête a été menée par le Centre international pour l'élevage en Afrique (CIPEA) sur la situation épidémiologique des principaux virus à tropisme respiratoire chez les petits ruminants au Mali. Les résultats obtenus prouvent leur existence à l'état endémique. Quelle que soit l'espèce, des anticorps neutralisants ont été décelés aussi bien chez les adultes que chez les jeunes. De nouvelles recherches sont nécessaires pour mettre en place une politique cohérente et efficace de prophylaxie ou de traitement selon le cas. Mots clés : Ovin - Caprin - Maladie respiratoire Virus - Épidémiologie - Mali.

\section{Introduction}

En zone rurale, les petits ruminants jouent un rôle important aussi bien sur les plans économique, nutritionnel que sociologique. Leur élevage est cependant confronté à nombre de problèmes, notamment d'ordre pathologique, et les contraintes de santé constituent une grave entrave à son développement (5). La pathologie dominante au Mali, comme partout en Afrique de l'Ouest, est identique et représentée par les pneumopathies $(1,2,3,4)$. Ce syndrome se manifeste surtout en saison sèche et froide (décembre à février) mais aussi en saison humide (hivernage). Cette note présente les résultats d'une enquête effectuée de 1986 à 1988 par le CIPEA sur la situation épidémiologique de certains virus à tropisme respiratoire au Mali, les travaux n'étant pas interrompus avec l'arrêt du projet.

\section{Matériel et méthode}

\section{Sérums}

L'enquête a porté sur 1591 sérums de petits ruminants. Le sang a été prélevé à la jugulaire et récolté dans des tubes bouchés sous vide. Chaque prise était accompagnée des commémoratifs suivants : espèce, sexe, âge. Après centrifugation les sérums ont été conservés à - $20^{\circ} \mathrm{C}$.

\section{Tests}

Ils ont été effectués à Dakar au Laboratoire national de l'élevage et de recherches vétérinaires du Sénégal. La méthode de séroneutralisation cinétique adaptée à

1. Centre international pour l'élevage en Afrique (CIPEA), Programme du Sahel, BP 60, Bamako, Mali.

2. Chef du service de Virologie du Laboratoire national de l'élevage et de recherches vétérinaires (LNERV), BP 2057, Dakar-Hann, Sénégal.

Reçu le 9.11.1990, accepté le 10.3.1992. chaque virus a été utilisée. Les sérums ont été testés visà-vis des virus suivants : IBR (rhinotrachéite infectieuse bovine) ; PI 3 (para-influenza 3) ; AD 5 (adénovirus type 5) ; BT ("blue-tongue" ou fièvre catarrhale maligne) ; EC (ecthyma contagieux) ; clavelée/variole ; PPR (peste des petits ruminants).

\section{Résultats}

Le tableau I montre la présence d'anticorps neutralisant chacun de ces virus. Les résultats par espèce et par groupe d'âge sont rapportés dans le tableau II. On note, quelle que soit l'espèce, la présence d'anticorps neutralisant les différents types de virus aussi bien chez les adultes que chez les jeunes. Sur le terrain, la présence permanente pendant la saison fraîche d'un nombre important d'animaux avec jetage nasal et toux est régulièrement constatée ; elle constitue le premier pic. Un second évolue en saison humide. Des foyers d'ecthyma contagieux, de clavelée/variole et de PPR, sont observés. Enfin, il faut signaler la présence de l'oestrose très répandue dans la zone et qui peut poser un problème de diagnostic différentiel en raison du jetage nasal.

\section{Discussion}

Les résultats confirment qu'il n'y a pas d'opposition entre les différentes données connues en Afrique de l'Ouest. Les principaux virus à tropisme respiratoire existent bien au Mali tout comme au Nigeria (8), au Sénégal (9) et en Mauritanie (6) mais, selon la fréquence des anticorps neutralisants, leur prévalence n'est pas la même que dans ces trois pays. Pendant la saison fraîche, ces pneumopathies évoluent de façon identique dans toute l'Afrique de l'Ouest. Les pertes indirectes enregistrée's sont importantes mais leur évaluation exacte est difficile sinon impossible du fait du caractère extensif de l'élevage. Dans le Delta du Niger, l'ecthyma contagieux représente chez les caprins 13 p. 100 de la morbidité et 2 p. 100 des mortalités totales (7). L'affection est constatée surtout chez les jeunes. La forme labiale est la plus

TABLEAU I Résultats des tests sérologiques aux différents virus à tropisme respiratoire.

\begin{tabular}{|lcrc|}
\hline $\begin{array}{c}\text { Types de } \\
\text { virus }\end{array}$ & $\begin{array}{c}\text { Nombre } \\
\text { de sérums } \\
\text { testés }\end{array}$ & $\begin{array}{c}\text { Nombre } \\
\text { de sérums } \\
\text { positifs }\end{array}$ & $\begin{array}{c}\text { Pourcentage } \\
\text { des sérums } \\
\text { positifs }\end{array}$ \\
\hline IBR & 1591 & 214 & $1,3,4(8,9-17,9)$ \\
PI 3 & 1591 & 420 & $26,4(22,3-30,5)$ \\
AD5 & 1591 & 1207 & $75,8(75,7-78,1)$ \\
BT & 1591 & 964 & $60,5(57,6-63,4)$ \\
EC & 1591 & 1053 & $66,1(63,4-68,8)$ \\
CLAV/VAR & 1592 & 200 & $12,5(8,0-17,0)$ \\
PPR & 1590 & 536 & $33,7(29,8-37,6)$ \\
\hline
\end{tabular}

Entre parenthèses : intervalles de confiance calcules au risque de 5 p. 100. 
TABLEAU II Résultats des tests sérologiques par espèce animale et par groupe d'âge.

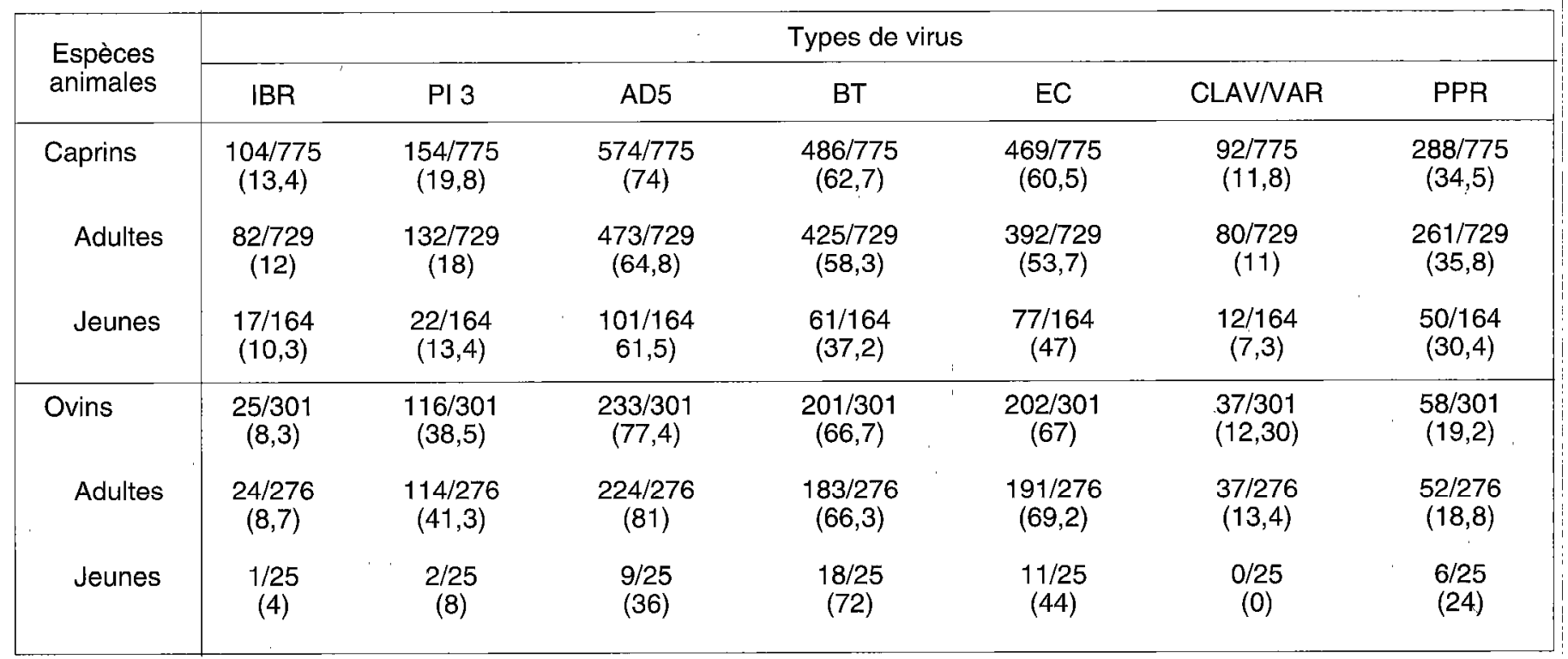

Numérateur : nombre positifs ; dénominateur : nombre testés. Entre parenthèses : positifs en $p .100$.

répandue au Mali. Des cas cliniques de PPR ont été confirmés par le laboratoire mais la maladie n'y a pas été aussi bien étudiée que dans les autres pays de la sousrégion. Dans le Delta central, la variole représente 28 p. 100 de la pathologie chez les ovins et 24 p. 100 chez les caprins (7). En zone agropastorale (Niono), ces taux tombent respectivement à 9,7 et 11 p. $100(10)$.

Selon les résultats des mêmes études $(7,10)$, elle constitue 17 p. 100 des mortalités chez les ovins et 29 p. 100 chez les caprins dans le Delta et respectivement 10,5 et 2,5 p. 100 dans la zone de Niono. Il ne faut donc pas sous-estimer son importance car la plupart des animaux qui en sont atteints meurent des suites de complications pulmonaires.

\section{Conclusion}

Ces résultats prouvent l'existence au Mali des principaux virus à tropisme respiratoire des petits ruminants, déjà connus en Afrique de l'Ouest. Le rôle effectivement joué par chacun d'eux dans le processus lésionnel fera l'objet d'études ultérieures avec isolement et typage des agents en cause.

Les pneumopathies des petits ruminants constituent un problème économique majeur.

Or, il existe actuellement peu de solutions sur le terrain. Au plan de la prophylaxie médicale, on citera la vaccination contre la PPR avec le vaccin antibovipestique
(Sénégal, Nigeria, Mali...), l'utilisation d'un vaccin antipasteurellique ovin-caprin au Mali et l'essai de vaccins polyvalents de Pasteurella multocida en Afrique du Sud.

Sur le plan curatif, l'association pénicilline-streptomycine et la terramycine sont, il est vrai, des plus efficaces, mais leur prix interdit toute action de masse. Les succès sont d'ailleurs très variables d'un pays à l'autre et les efforts doivent être intensifiés dans ce domaine pour mettre en place une politique sanitaire cohérente et adaptée aux cas particuliers des maladies respiratoires des petits ruminants au Mali.

Remerciements

Nous remercions les responsables de l'élevage malien et les chefs des secteurs de Mopti, Djenné, Douentza, Niono et Ténenkou pour l'aide qu'ils nous ont apportée dans le choix des troupeaux.

MAIGA (S.), SARR (J.). Epidemiological survey of the main respiratory viruses in small ruminants in Mali. Revue Élev. Méd. vét. Pays trop., 1992, 45 (1): $15-17$

From 1986 to 1988 a sero-epidemiological survey was carried out in Mali by ILCA to identifiy the small ruminant main respiratory viruses. The results of this investigation shows an endemic condition. Regardless of the virus species involved, neutralizing antibodies were detected in adults as well as in young stocks. New researches are necessary to set forth a consistent and effective policy of prophylaxis or treatment according to the case concerned. Key words : Sheep - Goat - Respiratory disease - Virus Epidemiolgy - Mali. 


\section{Bibliographie}

1. ADEOYE (A.O.). Incidence of diseases and pests in sheep and goats in two groups of villages in the forest zonte of South West Nigeria. In : Workshop small ruminant production systems in the humid zone of West Africa, Ibadan, Nigeria, 22-26 January 1989. P. 3.

2. Banque mondiale. Mission régionale en Afrique de l'Ouest, Mali : situation et perspective de l'élevage. Abidjan, 1980. P. 14.

3. BOURDIN (P.). Problèmes posés par la pathologie virale du mouton en zone sahélicnnc et soudano-sahélicnnc. Revue Élev. Méd. vét. Pays trop., $1979,32(2): 123-129$.

4. DOUTRE (M.P.). Rôle tenu par les bactéries et les mycoplasmes dans les affections respiratoires de la chèvre. Niort, 911 octobre 1984. P. 689694. (Les colloques de l'INRA $n^{\circ} 28$ )

5. DUMAS (R.). Contribution à l'étude des petits ruminants du Tchad. Revue Élev. Méd. vét. Pays trop., 1980, 33 (2) : 215-233.

6. LE JAN (C.), SOW (A.D.), THIEMOKO (C.), FRANCOIS (J.L.), DIOUARA (A.). Pneumopathies enzootiques des petits ruminants en Manritanie : situation d'ensemble et approche expérimentale. Revue Élev. Méd. vét. Pays trop., 1987, 40 (2) : 103-112.

7. MAIGA (S.). Principales maladies rencontrées chez les petits ruminants dans le Delta du Niger (Mali). Mali, CIPEA, 1987. (DP-AZ $n^{\circ}$ 178)

8. OBI (T.U.). Serological survey of peste des petits ruminants like viral infections in goats in Southern Nigeria. In : Workshop small ruminant production systems in the humid zone of West Africa, Ibadan, Nigeria, 22-26 January 1984

9. SARR (J.), DIOP (M.), CISSOKO (S.). Situation épidémiologique des principaux virus à tropisme respiratoire chez les petits ruminants $d u$ Sénégal. XII Journées médicales et pharmaceutiques, 18-23 janvier 1988, Dakar, Sénégal.

10. TRAORE (A.), WILSON (R.T.). Livestock production in central Mali : environmental and pathological factors affecting morbidity and mortality of ruminants in the agro-pastoral system. Prev. Vet. Med., 1988 (6) : 63-75.

\section{Epidemiology of contagious bovine pleuropneumonia (CBPP) in Northern states of Nigeria. An update}

\section{J.N. Nwanta ${ }^{1}$ \\ J.U. Umoh ${ }^{1}$}

NWANTA (J.N.), UMOH (J.U.). Épidémiologie de la péripneumonie contagieuse bovine dans les Etats du nord du Nigeria. Mise à jour. Revue Élev. Méd. vét. Pays trop., 1992, 45 (1) : 17-20

La présente étude porte sur une période de 20 ans (1970 à 1989). Elle confronte, année par année, les données concernant l'apparition d'épidémies de péripneumonie contagieuse bovine et la vaccination contre cette maladie, afin de déterminer la corrélation entre la vaccination et le nombre d'épidémies enregistré au Nigeria. Les résultats montrent que lorsque la vaccination a été intensifiée, de 1975 à 1986, les cas étaient moins nombreux. Le nombre de troupeaux atteints et le nombre total $\mathrm{d}^{2}$ animaux morts enregistrés dans les troupeaux était en augmentation à la fin des années 80 . Les données concernant la répartition saisonnière des épidémies révèlent qu'elle surviennent principalement au cours de la saison sèche (octobre à mars). Lorsque les données concernant la répartition géographique étaient inscrites sur une carte, selon les renseignements livrés par les fichiers sur les épidémies, il apparaissait qu'elles étaient principalement localisées au bord des cours d'eau. En outre, la morbidité des pays avoisinants était corrélée aux problèmes épidemiologiques du Nigeria. Mots clés : BovinPéripneumonie contagieuse bovine - Vaccination - Enquête pathologique Épidémiologie - Nigeria.

1. Department of Veterinary Public Health and Preventive Medicine, Ahmadu Bello University, Zaria, Nigeria.

Reçu le 19.3.1991, accepté le 25.2.1992.

\section{Introduction}

Contagious bovine pleuropneumonia (CBPP) is caused by Mycoplasma mycoides var. mycoides (15) and is characterised by marked oedema of interstitial tissues in the lung, diffuse pneumonia and serofibrinous pleuritis (1). It plagued cattle in Europe and elsewhere in the 19th century as well as in Africa at the present time $(1,4,6,22)$.

Contagious bovine pleuropneumonia has occurred in Northern Nigeria for many years, causing generally high morbidity and mortality. Annual reports show a fluctuating number of outbreaks from time to time especially among the trade cattle $(1,12,22)$.

The results of efforts to control CBPP are fluctuating. Reports show that the disease was controlled by 1965 , but unfortunately it re-emerged (16). An attempt towards a regional international campaign for eradication of CBPP in West and Central Africa started in 1969. Nigeria launched the joint project (JP28) in 1974, although the actual campaign started in 1971 (6). When vaccination increased, the number of outbreaks decreased. At present, there is an upsurge of the disease across the country. The aim of this short communication is to reveal the outbreak pattern, the relationship between outbreaks and vaccination coverage, seasonal distribution pattern and geographical location of the outbreak in relation to the disease situation in the frontier countries.

\section{Materials and Methods}

Data on CBPP outbreaks and vaccination figures in Nigeria for a twenty-year period (1970-1989) were collected from disease outbreak report files in Epidemiology, and National Rinderpest/CBPP co-ordination Units of the Federal Livestock Department, Kaduna. They were plotted against the respective years to determine the relationship between vaccination campaign and incidence of CBPP in Nigeria. Data on monthly outbreaks for Kaduna, Kano and Sokoto from 1984-1986, were also collected from the same source and monthly variation for the reported outbreaks determined using the ratio-to-moving average method (13).

Other data collected include general outbreaks information in ten Northern states between 1985 and 1989.

Finally, information on CBPP situation in the neighbouring countries with respect to their control policies and results were collected with relationship to our control problems.

\section{Results}

Table I shows that the number of outbreaks is increasing since 1986. The number of doses of vaccine used is decreasing. The relationship between the vaccination campaign and the number of outbreaks is shown in figure 1. When the vaccination was intensified between 1975 and 1986, the number of outbreaks was low. Also on the increase in late 1980s were the number of affected herds and the total number of deaths recorded in the affected herds. 